\title{
The implementation of Mind-mapping technique to improve student's Descriptive text writing ability
}

\author{
Naomy Dwi Saraswati ${ }^{1}$, Mahpul ${ }^{2}$, Dian Shafwati ${ }^{3}$ \\ Universitas Lampung, Jl. Prof. Dr. Sumantri Brojonegoro, Rajabasa, Bandarlampung ${ }^{1,2,3}$ \\ ${ }^{1}$ Correspondence: naomysrs@gmail.com
}

\begin{abstract}
The objectives of this research were to find out if there was any significant difference on students' writing ability in a descriptive text before and after the implementation of mind-mapping technique and to investigate the students' perception toward the use of mind-mapping technique in teaching writing ability. The population of this research was the first year students of SMA Surya Dharma 2 Bandarlampung. The sample of this research was X Science 1 which consisted of 33 students. The data were taken from the tests and they were analyzed by using paired sample t-test. The result of the research showed that there was a significant difference on students' writing ability since t-value $>$ t-table $(20.967>2.0345)$. The mean score of post-test $(68.98)$ and the pre-test score (62.73). It gained 6.25. In addition, the second result showed that the mean of the questionnaire was 78.78. It means the students' perception toward the implementation of the strategy was positive. Most of the students agreed that the strategy was applied in teaching reading process. Briefly, it could be concluded that mind-mapping technique enabled to improve the students' achievements in writing ability and showed positive impact to students toward the use of the technique in teaching process.
\end{abstract}

Keywords: Writing ability, Descriptive text, Mind-mapping technique

\section{INTRODUCTION}

In learning English as a foreign language, writing is one of the language skills which are important for students to master. According to Byrne (1995) writing is transforming our thoughts to become language or written form. In writing, any idea that you advance must be supported with specific reasons or details (Langan, 2008). Writing is important knowledge which is going to be very useful for the people to communicate with the others and also express their feelings through written text. Expressing something can be done not only through speaking but also through written text which has to be factual and valid. Thus, learning how to write in English well is very important for students.

In writing, the students do not only focus on how to write good sentences or make good paragraphs but it must have good content. However, there are also some aspects of writing that have to be concerned before they start writing. First, vocabulary which is used in making a sentence or 
paragraph must be appropriate. Second, grammar must be used in proper situation and it has relation in using what tenses which is appropriate for the idea. Third, organization of the sentence or paragraph should be concerned and arranged in good arrangement in order for the readers can understand what they are going to read after looking at the text or sentence that the students have written. The last is mechanic which means in writing a sentence or paragraph, students should be aware of putting the symbol, numbering and also the punctuation that a text can be understood easily.

Although mastering writing is very important, teaching writing as a foreign language should be done in a unique strategy and also be taught in good sequences in order the students could understand easily. Cumming (2001) has stated that different theoretical orientations tend to focus on different aspects of writing.

Due to students' ability and their needs analysis are different, a teacher has to be sensitive and creative in designing a lesson plan for teaching writing to the students. Some students are probably good in grammar but they lack in vocabularies and also some students are probably good at giving ideas to their writing but they lack of grammar and these are some reasons teaching writing is not only focused on how to write in English well but also how to teach the students to use proper language and good structure to share their ideas in written form.

Moreover, most of the students in SMA Surya Dharma 2 Bandar Lampung perceive that writing is a very difficult activity. They find out that it is hard for them to learn grammar and also the other aspects of writing and some students assume that writing is a boring activity. Teachers have to think quickly to solve this problem. They have to think creatively in making a lesson plan or decide what strategies which they will apply in the teaching and learning process. There are also various techniques for teaching writing. In implementing a technique for teaching writing, a teacher must be creative that it can attract students to follow the explanation which is given by the teacher easily. Teachers can use technique in their learning process and to make the learning process be done properly and understood by the students easily. By using an appropriate technique, teachers can develop their material to improve students' motivation to learn writing. Mallof (2004) has stated that there are some strategies which can be used to motivate students to learn writing.

Nevertheless, teachers have to find out some techniques which can be used in teaching writing. One of them is mind-mapping technique. According to Axelrod and Charles (1985) mind-mapping is an invention activity which reveals possible relations among facts and ideas. This technique requires the students to prepare brief note about the ideas which are relevant with the fact of the topic that will be written. Technique gives students freedom to think the things which have relations with the material or the topic which they are going to discuss.

Thus, in this research, the researcher used mind-mapping technique to teach descriptive text writing to the first-grade students of senior high school. There are some previous studies which used mindmapping technique in the learning process, The first study is conducted by Amalina (2007) which 
used mind mapping in her research entitled Relationship between students' perception toward the teaching and learning methods of mathematics' lecturer and their achievement in pre-university studies has proved that even though the value of mean for each dimension of teaching and learning shows that the students' perception was in good and excellent category, it does not mean that their Mathematics achievement also good. The second, the study which conducted by Manalu (2019) showed that mind mapping technique can increase students' writing skill and it also improves the students' skill in five aspects of writing namely: content, organization, vocabulary, language use, and mechanic.

Finally, the researcher chooses this technique to teach writing and to find out the answers of the research questions about the improvement of students' descriptive text writing ability after the implementation of mind-mapping technique and correlation between students' perception and their writing achievement after the implementation of the technique.

\section{METHODS}

This study adopts a quantitative approach with one group pre-test post-test design, in which there is one group as the sample (Setiyadi, 2018). The population for this research is the students at the first grade of SMA Surya Dharma 2 Bandar Lampung in academic year 2019/2020. For the sample, the researcher chooses 33 students from $X$ Science 1 by using purposive sampling. The data are collected by using tests (pre-test and post-test) and questionnaire. Then, the improvement of students' test results are analyzed by using paired sample t-test in SPSS (20.00) to figure out whether any improvement of students' writing ability. In addition, to know the students' perception after the implementation of mind mapping technique the researcher computes the data by using SPSS (20.00) then analyzes it descriptively.

\section{RESULTS AND DISCUSSION}

\section{Results}

After conducting the research, the researcher gathers the result of the pre-test and post-test after the implementation of mind-mapping technique as follows:

Table 1 Distribution of the Students' Scores in the Pre-test and the Post-test

\begin{tabular}{|c|c|c|c|c|c|c|}
\hline $\begin{array}{l}\text { Interval } \\
\text { Score }\end{array}$ & $\begin{array}{c}\text { Fi of } \\
\text { Pre-test }\end{array}$ & Percentage & Mean & $\begin{array}{c}\text { Fi of } \\
\text { Post-test }\end{array}$ & Percentage & Mean \\
\hline $45-53$ & 4 & $12.12 \%$ & \multirow{5}{*}{62.73} & 1 & $3.03 \%$ & \multirow{5}{*}{68.98} \\
\hline $54-62$ & 11 & $33.33 \%$ & & 5 & $15.15 \%$ & \\
\hline $63-71$ & 11 & $33.33 \%$ & & 15 & $45.45 \%$ & \\
\hline $72-80$ & 6 & $18.18 \%$ & & 11 & $33.33 \%$ & \\
\hline $81-89$ & 1 & $3.03 \%$ & & 1 & $3.03 \%$ & \\
\hline Total & 33 & $100 \%$ & 62.73 & 33 & $100 \%$ & 68.98 \\
\hline
\end{tabular}


Table 1 shows that the mean score of the pre-test is 62.73 and in the post-test, the mean score is 68.98. It means that there is a significant difference after the implementation mindmapping technique in teaching writing ability.

In order to see the significance level of students' writing improvement, the researcher analyzed the data by using Paired Sample T-test. Besides, this test was used to prove whether the alternative hypothesis $\left(\mathrm{H}_{1}\right)$ is accepted or not. The researcher also compared the result of t-value and t-table to determine whether the alternative hypothesis can be accepted or not. The result is shown in the following table:

Table 2 T-test Results of the Hypothesis

\begin{tabular}{|c|c|c|c|c|c|c|c|c|c|}
\hline & & \multicolumn{5}{|c|}{ Paired Differences } & \multirow[t]{3}{*}{$\mathrm{T}$} & \multirow[t]{3}{*}{ Df } & \multirow{3}{*}{$\begin{array}{l}\text { Sig. }(2- \\
\text { tailed) }\end{array}$} \\
\hline & & \multirow[t]{2}{*}{ Mean } & \multirow[t]{2}{*}{$\begin{array}{c}\text { Std. } \\
\text { Deviation }\end{array}$} & \multirow[t]{2}{*}{$\begin{array}{c}\text { Std. Error } \\
\text { Mean }\end{array}$} & \multicolumn{2}{|c|}{$\begin{array}{c}95 \% \text { Confidence } \\
\text { Interval of the } \\
\text { Difference }\end{array}$} & & & \\
\hline & & & & & Lower & Upper & & & \\
\hline $\begin{array}{l}\text { Pair } \\
1\end{array}$ & $\begin{array}{l}\text { Post-test - } \\
\text { Pre-test }\end{array}$ & $\begin{array}{r}6.257 \\
58\end{array}$ & 1.71447 & .29845 & 5.64965 & 6.86550 & 20.967 & 32 & .000 \\
\hline
\end{tabular}

Null hypothesis is rejected if t-value $>\mathrm{t}$-table with the level of significance at $<0.05$. From the data in Table 4.6, it could be seen that $20.967>2.0345$ and $0.00<0.05$. Therefore, for the hypothesis, the research hypothesis was accepted. Moreover, viewed from the mean score of pre-test and post-test, the students' score improved 6.25 points from 62.73 to 68.98 .

\section{Graph 1 The Result of the Questionnaire}




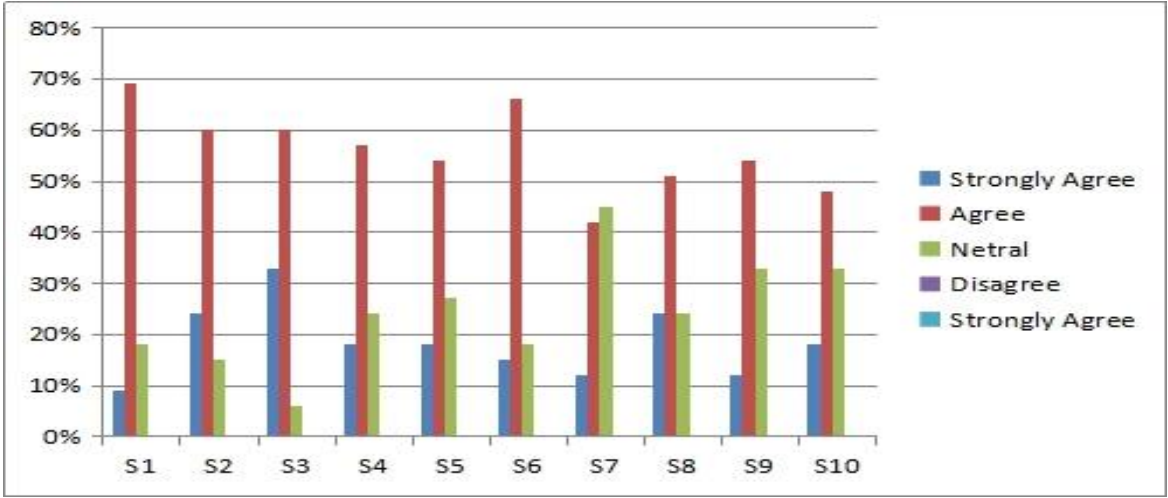

From the graph above, it can be said that the students' perception toward the implementation of mind-mapping technique is mostly positive. It can be seen from a number of their positive answers that support the implementation of mind-mapping technique.

\section{Discussions}

\section{The Improvement of Students' Writing Ability through Mind-Mapping Strategy}

This research had showed that there is a significant improvement of the students' writing ability before and after the implementation of mind-mapping technique. The significant difference of the students' writing ability can be seen from the comparison between the students' pre-test score and post-test score and the result of paired sample t-test. After did the research, the researcher and the English teacher analyzed the students' scores to know whether there is an increase of the students' writing descriptive text or not. The result of the mean score of the pre-test is 62.73 and the post-test is 68.98. The increase of the means score is about 6.25 . So, it can be said that there is a significant difference of the students' writing descriptive text by using mind-mapping technique.

In this research, the students gained an improvement after the implementation of mind mapping technique for their writing scores. Besides, the researcher also found that mind-mapping technique can improves students' writing ability in all aspects of writing. They are content, organization, vocabulary, language use, and mechanic. From five aspects of writing, the highest score was content. The increase is 2.38 . It was because on the pre-writing, the students had already had the ideas about the topic they were going to write by making the mind map. Besides, the students were active and got new vocabularies by making the keywords as the ideas. It was also easier for the students to make the content of their writing because on the drafting session they just needed to elaborate their ideas became sentences, gave the number in each sentence based on the generic structure of the descriptive text and arranged the sentences into paragraphs.

Furthermore, the aspect with the lowest increase was mechanic with the mean of the pre-test and post-test was 0.41 . This happened because the researcher did not ask the students to produce active and passive sentences in form of simple present tense as the language feature of descriptive text so 
that most students were still incorrect in writing simple present tense sentences. The researcher also did not explain about countable, uncountable noun, gerund, and the article; a, an, and the. It made the students did not use the article before the singular countable noun and gerund after preposition. Moreover, the researcher put mechanic's percentage in the lowest range than the other aspect in scoring criteria of each aspect of writing.

Through mind-mapping technique, the students were given a guideline in the form of pictures in writing descriptive text to help the students to make the ideas. By having mind maps, they have something to write and their piece of writing would be well organized. It also supports Mercer's statement (2002) who said that mind mapping can help writers stick to the topic by having their ideas in front of them as they are writing. It is similar to what the researcher found during the treatments. Before getting the treatments, the students had difficulties in conveying their ideas by writing. It made their writing disorganized and poorly written. However, after getting the treatments, their writing became better and smoother. It means that it is good for the students because mind mapping helps the students to organize and create the ideas as many as they can before they move on writing. That makes the students can be easily to write because they only need to elaborate the ideas. So, It can be said that mind mapping is effective for the students to do writing and the students in this research were helped in writing descriptive text through mind-mapping technique.

\section{The Students' Perception toward Mind-Mapping Technique}

The second research question of this research is to know how the students' perception toward the implementation of mind-mapping technique in teaching writing. The researcher used the questionnaire to collect the data. It was used in order to support quantitative data. It consisted of 10 statements which were categorized into interest and experience. The interest aspect was to find out whether students were interested toward the implementation of mind-mapping technique. Meanwhile, experience aspect was to find out what advantages that they got based on their experience after they were taught through mind-mapping technique.

In this research, the most of students enrolled an agreement with the statements that mind-mapping technique is an interesting technique which gave benefits for the students in writing achievement. There were $80.60 \%$ of students who answer agreement in interest aspect. It means that the students were interested in teaching learning process by using mind-mapping technique. This occurred because while they learned through mind-mapping technique, each of them had the opportunities to write their idea. In line with Seow (2002) has stated that mind-mapping is a simple yet powerful strategy. Mind-mapping technique can be very effective way for the students who are difficult to show their feelings or difficult to write long sentences directly. So, it made students became active in learning process. In addition, while learning through this technique, students discussed their work with their friends within the group. In this discussing activity, they felt enthusiastic because they could interact with their friends. 
In addition, because the students were interested in mind-mapping technique, their achievement in descriptive text writing was also improved. It is accordance with Del Favero, Boscolo, Vidotto, and Vincentin (2007) who states that interest combines both affect and cognition and is shown to have the energizing function for deeper learning. It means that the interest is very affecting to students in learning. Interest is also energy in the learning process. With the interest, students will be more motivated to learn. They will learn more about a topic. Then, they become more skilled and knowledgeable.

Besides, there were $76.96 \%$ of students' answers showed agreement in experience aspect. It means that the students got many benefits from the implementation of mind-mapping technique. It was because mind-mapping technique is a good technique that can help students memorizing something because it enables us to arrange the facts and ideas and also show the overall structure of a subject and the relative importance of individual parts of it. It helps students to associate ideas, think creatively, and make connections that might not otherwise make. The students used it in the early stages of planning an essay in order to find sub topic in a topic to organize information and start to write their ideas but they can only use word or phrase which related to the topic. Furthermore, the students sure to respond the questionnaire positively because they got experiences from the teaching learning process.

From the explanation above it can be concluded that the students' perception toward mind-mapping technique was mostly positive. It could be seen from a number of their positive answers that support the implementation of mind-mapping technique. It is in line with Riduwan (2007) who states that the result of questionnaire is positive if the participants' responses of the questionnaire are not lower than $41 \%$.

\section{CONCLUSIONS AND SUGGESTIONS}

\section{Conclusions}

Based on the result of this research, there is a significant difference of students' descriptive text writing ability before and after the implementation of mind-mapping technique. It can be seen from the means score of pre-test is 62.73 and in the post-test is 68.98 ; the increased is 6.25 . the use of mind-mapping technique is effective in learning activity and increasing students' writing ability and also all aspects of writing. Furthermore, Most of the students agreed that using mind-mapping technique made them easier to learn English and they felt relaxed in doing all of the procedures. It can be stated that the students' perceptions toward mind-mapping technique positive in each statement.

\section{Suggestions}

The researcher would like to recommend some suggestions to the English teachers to apply mindmapping technique as one of the alternative ways to increase the students' writing descriptive text. This is due to mind-mapping technique can help the students who still have the problems in 
expressing their ideas in written form to generate their ideas related to the topic and also suggested to use media in teaching writing by mind-mapping technique while the treatments, such as: pictures, videos, and posters. It is because most of the students are more excited when the teacher uses media in teaching learning activity. Besides, the activities in the class will be more fun. The English teachers are suggested to discuss more detail in form of language use especially about countable, uncountable noun, gerund, and the article; a, an, and the. Moreover, the researcher should ask the students in producing their own sentences in form of active and passive voice as the language feature of report text. The researcher only focused on the increase of students' descriptive text

writing ability, so for the further researchers may investigate the effect of mind-mapping technique in another skill of English such as reading, listening and speaking and also try to find out other types of texts besides descriptive text, for example: report text, narrative text, procedure text, and etc. The loading aspect of writing should be the consideration.

\section{REFERENCES}

Amalina, N. (2017). Relationship between students' perception toward the teaching and learning methods of mathematics' lecturer and their achievement in pre-university studies. International Journal of Education Studies, 10(11):129.

Axelrod, R. B. and Charles R. C. (1985). The t. martin's guide to writing. New York: St.Martin's Press.

Byrne, D. (1980). Principles of language learning and teaching. New York: Longman Group.

Cumming, A. (2001). Learning to write in second language: Two decades of research. International journal of English studies, 1(2),1-23.

Del Favero, L., Boscolo, P., Vidotto, G., \& Vincentini, M. (2007). Classroom discussion and individual problem-solving in the teaching of history: Do different instructional approaches affect interest in different ways. Learning and Instruction, 17(6), 635-657.

Langan, J. (2008). College writing skills. New York: McGraw-Hill Companies.

Mallof, J. (2004). Nine ways teachers can help young students overcome shyness. Sydney: University of New England. 
Manalu, S. O. (2019). Improving students' ability in writing report text through mindmapping technique at the second grade of SMAN 3 Bandar Lampung. English Department, Teacher Training and Education Faculty, Lampung University.

Mercer, N. (2000). Words and minds: How we use language to think together. London: Routledge.

Riduwan. (2007). Rumus dan data dalam aplikasi statistika. Bandung: Alfabeta.

Seow, A. (2002). The writing process and the process writing. Cambridge: Cambridge University Press.

Setiyadi, A. B. (2006). Metodologi penelitian untuk pengajaran bahasa asing, pendekatan kuantitatif dan kualitatif. Yogyakarta: Graha Ilmu. 